\title{
Spirit, Demons, And Mental Disorders In Nepalese Culture, Some Historical Aspects
}

\author{
Upadhyaya KD
}

\author{
Senior Psychiatrist, Kathmandu Model Hospital E Advisor CMC-Nepal
}

E-mail *Corresponding author: $\underline{\text { drkapilupadhyaya@gmail.com }}$

To understand this concept, we have to go to pre-Vedic era prior to $1500 \mathrm{BC}$. The role of heavenly bodies in pathogenesis of mental disorder is a Mesopotamian concept. Attributing illness to demons and treating them by magic, divination and temple healing were to some extent imported from contemporary civilization of Mesopotamia, Egypt, Crete and India. ${ }^{1}$ In Nepalese culture, mental disorders particularly psychotic disorders means curse by God for some unknown deeds or past Karma, by evil spirit or sorcery by enemies. Worship to God to please Him or to evil spirit as advised by the priest; Mata (women having special power to heal) or by the traditional faith healers are often performed before seeking medical treatment by over $90 \%$ of the families for psychotic patients.

To understand methods of healing by traditional healers², I interviewed 30 traditional healers active in such practices. One of the healer claimed that they are the real healers for mental disorders cases, and modern doctors though they have certificate, do not know anything about such illnesses. Such is the belief amongst many faith healers, which they go on telling to patients and their families. Other faith healers were also not different in the sense that all of them believed different kinds of evil spirits as the causes of the illness and different methods of healings depending upon the type of evil spirit. Frank, J.D. a researcher in modern medicine, writes that certain patients of his, a priest or a sorcerer would be more appropriate than a trained psychiatrist. ${ }^{3}$

Psychiatrists know in their day-to-day practice that some psychiatric disorders like acute transient psychotic disorders, and some neurotic disorder may recover without any treatment. Psychiatrists or traditional healers often get credit for recovery of illness, if such cases had consulted them, and recovered in a very short period like within a week.

The Vedas are the oldest books in the library of mankind. ${ }^{4}$ There are four Vedas, namely RigVeda, Sama-Veda, Yajur-Veda and Atharva Veda.. Medicine and psychiatry hail from Atharva Veda. Atharva Veda deals exclusively with spirits and ghosts. So our belief system in evil spirits and ghosts as the cause of mental disorder is rooted from ancient time, based on our oldest scriptures like Vedas. Blaming patients, and their family members or the communities will not help in the management of mental disorders, as this belief has strong link with our culture.

Many of our mental patients also come with amulet in upper arm or Jantar in their neck. According to Charaka Samhita, the powers of amulet are equal to thousands of medicines given by thousands of practitioners. ${ }^{5}$ Charaka was one of the principal contributors in Ayurveda, so amulet and Jantar also have strong base in our culture. Confidence in amulet or Jantar, will give placebo effect or psychotherapeutic benefits to patients even if there is no scientific evidence of effectiveness, or if we question their roles.

Charaka mentions several factors or etiology of insanity. An evil deed, living alone in a house or passing through a crossing of four roads (such places are supposed to be haunted by evil spirit), sexual intercourse at twilight, on full moon or on new moon nights, or with a menstruating women, improper recitation of scriptures, defective ceremonials, breaking celibacy in brahmacharya, non-observance of rituals at the time of solar and lunar eclipse, visit to holy places or temples in an unclean and improper state remaining unclean after eating 
meat, honey, till or gur or after passing urine or stool, walking at nights at cross road, cremation grounds or slaughter houses, or insulting a Brahmin, teacher, Gods, and ascetics. ${ }^{6}$

Most of the causes given above are believed and a few of them also followed by rural community and old generations. These are some of the important issues to be considered and dealt carefully while treating mental disorders cases. Cultural belief system takes long time to change. There are also Ayurvedic medicines and Tibetan Medicines for mental disorders and epilepsies. Qualified doctors in Ayurveda and Tibetan medicine treat mental disorders. I have met some Tibetan doctors who combine prayer, meditation, mantra chanting, massage and Tibetan medicine to treat various physical diseases and mental disorders.

In conclusion, our belief system is very ancient, rooted to Vedic period, Traditional healer's faith healing is also based on their own science which they want to keep secret. There are other different methods of healing like acupuncture, acupressure, Reiki, a Japanese system of healing, distant healing and well established method of treatment like Ayurveda, Tibetan medicine, Homeopathic Medicines and Allopathic medicines which have their own methods, and limitations. Let our patients benefit which ever method they choose and apply.

\section{REFERENCES}

1. A Venkoba Rao; Psychiatric thought in ancient India; Presidential Address IJP Vol 20(1) 1978.

2. Upadhyaya K. D. Traditional healers of Nepal and Faith healing. Proceedings of National Seminar on Implementation of National Mental Health Policy: $\mathcal{E}$ Symposium on "Alternative Approaches to Mental Health Service" June 22, 1999 (pp 156 -167)

3. Frank, J.D.(1974). Forword: Magic, Faith and Healing: The Free Press, New York

4. Siddhantalankar, S.(1969). Heritage of Vedic culture. Taraporevala and Sons, Bombay

5. Charaka Samhita (1949). Shree Gulab Kunverba Ayurvedic Society, Jamnagar, India

6. Varma L.P. (1974). Some ancient Indian concepts on mental health. Indian Journal of History of Medicine.19:45 